\title{
Implementation of Multicultural Islamic Education Values
}

\author{
Sismanto Sismanto ${ }^{1, *}$ Maskuri Bakri ${ }^{1,}$ Achmad M. Huda ${ }^{2}$ \\ ${ }^{1}$ Islamic University of Malang, Malang, Indonesia \\ ${ }^{2}$ State Islamic University Sayyid Ali Rahmatullah Tulungagung, Tulungagung, Indonesia \\ *Corresponding author. Email: sirilwafa@gmail.com
}

\begin{abstract}
This article analyzes and discusses the implementation of values, models, and strategies of multicultural Islamic education in elementary schools using a qualitative approach with multi-site in SD YPPSB 3 and SDN 002 Sangatta. The author collects data through interviews, FGDs, and explores several relevant references, documents, and other relevant data. The findings reveal that: (1) The values of multicultural Islamic education are formulated in the school's vision and mission through school meetings attended, foundation management, school principals, teachers, and stakeholders, (2) The multicultural Islamic education curriculum development model uses administrative and grassroots models, and (3) Its implementation strategy through curriculum integration in each lesson, extracurricular activities, and habituation in school and daily home environment.
\end{abstract}

Keywords: Multicultural, Islamic education values, Curriculum development, Implementation.

\section{INTRODUCTION}

Indonesia is a country that has a variety of cultures, ethnicities, customs, religions, and languages. Indonesia consists of 35 provinces stretching from Sabang to Merauke from Miangas island to Rote Island as an archipelagic country. Indonesia has approximately 17,000 islands, 250 ethnic groups, and 500, and each province has its own culture, language, and ethnic food [1-3]. As a multicultural country, Indonesia has its distinctive style of multiculturalism based on the cultural joints typical of Pancasila. The presence of multiculturalism in Indonesia is a wealth for the Indonesian people and not a barrier. Multiculturalism recognizes that the diversity that exists in Indonesia must be maintained, cared for, and preserved [4].

In today's era, demands for equality of human dignity before the law and the enforcement of human rights are increasingly appearing on the surface. The existence of an intolerant and discriminatory attitude towards humans is a problem that needs to be resolved. School as a social system is an optimal and conducive place and can strengthen religious moderation in a pluralistic and diverse society. Indonesia has a history of horizontal conflicts, which started from friction between individuals and between tribes in Ambon, Poso, and various other places [3]. Noor Sulistyobudi et al. mention the number of student violence in the Special Region of Yogyakarta (DIY) based on the records of the Yogyakarta Police; in 2011, there were 9 cases. In 2012 and 2013, there were 5 cases. The case of violence among the student needs to be observed so that similar issues do not reappear. The patient does not originate from SARA problems (violence between customs, cultures, ethnicities, and religions) because learning is an age in searching for entities and identities [5].

Conflicts between religious communities in Indonesia have recently highlighted the need for an education system to address religious intolerance through religious education and religious culture in schools [6]. The spirit of religious education must be maintained in schools that contribute to making an area a tolerant city [7]. Integrating integrated Islamic education combines Islamic studies, science, and technology [8]. Shifting the paradigm of Indonesian education that religious education must be rooted in a multicultural perspective supported by theological insight [9]. Law No. 20 of 2003, which also regulates multiculturalism in educational institutions, emphasizes multicultural education in schools.

Thailand's multicultural education policy provides opportunities for migrant students to access public education [10]. The results of a comparative study in 
Indonesia and the UK show that religious education in Indonesia has a mono-religious focus, only teaching students about their own religious beliefs and identities, so they tend to support spiritual judgment and commitment. At the same time, the UK is more open and introduced to other religions [11]. Inconsistency between multicultural education policies and practices due to lack of explicit policy and education decision-makers and teachers [12].

According to James A. Banks, multicultural education consists of at least three things: ideas, educational reform movements, and processes aimed at changing the structure of educational institutions [13, $\mathrm{p}$. 3]. Presence multiculturalism is common in region, class, age, and gender, and race and ethnicity [14]. Sleeter provides a framework that helps educators articulate implementation-focused multicultural education issues [15]. Its Sleeter's implemented diversity among students with different cultural backgrounds, including those with different ethnicities, religions, mother tongues, social classes, physical limitations, and sexual orientations [16]. Bennett's research provides a conceptual framework for a research genre that describes the multidisciplinary roots of valuable multicultural education for designing programs and preparing new teachers [17].

The role of teachers in the implementation of multicultural education as researched previously. The researchers explain that preservice teachers in teacher education programs have a critical attitude towards multicultural attitudes [18,19]. Preservice teachers are aware of and accept multicultural perspectives [20,21]. online blogs can promote the growth of preservice teachers in multicultural education classrooms [22]. and the differences between the objectives, content, teaching process, and assessment methods of preservice teachers [23].

In the multicultural learning process, schools have a role in maintaining multicultural student relationships [24]. Learning multicultural helps encourage harmony between people from various cultural and religious backgrounds [25-27]. Likewise, the practice of learning in Islamic boarding schools teaches multiculturalism [28]. Learning media such as textbooks also play a role in building multiculturalism [29,30]. Web 2.0 technology can be an essential tool for students and teachers in building multiculturalism [29].

Tracing the results of several research studies on the implementation of multicultural education such as; in Early Childhood Education, to increase the physical, intellectual, social, emotional growth of early childhood under three years in Indonesia [31], in high school [25], at the boarding school [28], in junior high school [32], and the implementation of local wisdom-based multicultural education in Indonesian elementary schools [33]. Using Abdullah Saeed's thought study to construct the values of the Qur'an as the basis for the development of Islamic education [34].

It is considering that no research examines the learning of multicultural Islamic values in elementary schools. Therefore, this paper focuses on how the learning process in the classroom instils multicultural Islamic values. Thus, this research becomes essential for schools to reflect on diversity. What is unique in this research is that it belongs to the current study that focuses on Islamic education researchers. Although it has been practiced for a long time, the facts show that the phenomenon of multicultural Islam in building a tolerant culture through the process of enjoyable, innovative multicultural learning and methods that are following the characteristics of the school.

\section{METHODS}

This research used a qualitative approach with a multi-site type, which requires researchers to involve several places and research subjects at once [35]. In the design of this study, the researchers involved two elementary schools located in the city of Sangatta, namely SD YPPSB 3 and SDN 002 Sangatta Utara, Esat Kutai, Kalimantan. The first reason is that this city was chosen based on several considerations of the uniqueness, uniqueness, and position of Islam as a minority religion here, while these two elementary schools were chosen based on considerations of different backgrounds, namely private and public which best accommodates several problems, especially the compatibility of values studied in Islamic multicultural. From these various places and subjects, the researcher collected some data through interviews, observations, FGDs, and document checking.

During the observation, the researcher made direct observations with the aim of knowing all the units and parts in the organizational structure in detail including (1) what are the values of multicultural Islamic education, (2) the existing organizational structure, and (3) a description of the initial data about anything that can support the research focus.

Furthermore, this interview technique is addressed to Islamic religious education teachers and other parties who are indirectly involved, such as foundations, school principals and vice principals of the curriculum section, committees which are intended to collect data as follows: (1) Experiences of stakeholders in implementing values the value of multicultural Islamic education; (2) the problems faced by stakeholders in implementing the values of multicultural Islamic education; (3) The potential of stakeholders to develop the values of multicultural Islamic education; (4) Stakeholder understanding of the concept of multicultural Islamic education values. Meanwhile, checking the documents studied included the lesson plans syllabus, worksheets 
distributed in class, student assignments, and sample exam questions. And finally, the FGDs conducted in this study focused more on examining the findings of several competent parties in this field.

\section{RESULTS AND DISCUSSION}

\subsection{Multicultural Islamic Education Values}

The school that the researcher uses as the research location is a multicultural school. It can be used as a foothold to find a conceptual building to construct multicultural Islamic education values formulated through school leadership meetings. The development of multicultural Islamic values consist of; (1) the school's vision and mission; (2) curriculum; (3) leadership and management; (4) culture; (5) student activities; and (6) the cooperation of the wider community. The following picture can be seen in detail to clarify further the elements that influence the development of Islamic educational values in schools.

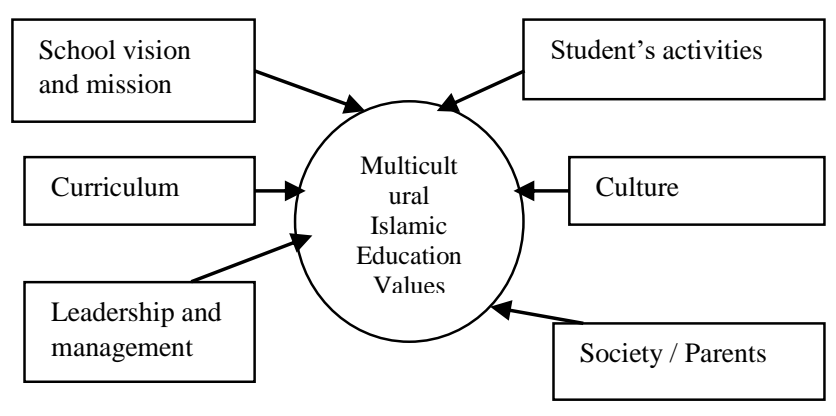

Figure 1 Elements involved in the development of multicultural Islamic educational values.

Based on the picture above, the development of multicultural Islamic values begins with school meetings. The meeting was attended by the management of the foundation and school stakeholders. The principal, teachers, and representatives of parents also participate in this meeting. Multicultural Islamic education in its implementation is formulated by the principal, who can develop its vision and mission. The principal has the authority to determine the policy direction for the development of Islamic values in the school he leads; of course, the formulation of ideas and models of multicultural Islamic education is passed through an annual meeting with teachers and representatives of parents or stakeholders. According to Raihani's findings, the school's vision and mission are the directions and guidelines for multicultural education [12]. Raihani added that the principal's leadership has some aspects in realizing the school's vision and mission. At the same time, managerial ensures the stability of the process by carrying out its administrative functions.

The quality of curriculum and teaching is at the core of the process and provides the primary resource for understanding cultural diversity and developing multicultural attitudes. The goals and content of the curriculum that explicitly contains the teachings of multiculturalism reflect the school's vision, and the learning facilitates the achievement of these goals. The curriculum can reference and guide education implementers, especially teachers, in managing teaching and learning activities. Teachers at school and parents can also see the curriculum that can be used as a guide to guide their children to study at home. The existence of the curriculum will also assist the principal in carrying out learning supervision. Likewise, for the community, looking at the curriculum can be used as a foothold to help realize the learning process in schools.

The quality of the learning process is about teaching with the right pedagogical and technical skills. Teachers have wholehearted values to respect the uniqueness and needs of each student. According to Sismanto's opinion, the teacher's teaching style must follow the student's learning style [36]. A high-quality learning process will not be achieved without continuous professional development for teachers and other staff to build their capacity [37]. In addition, quality teachers can create a supportive culture for children to live together and in diversity. According to multicultural education, deliberate and explicit action for creating rituals, norms, and standards must be taken to build a school culture that supports a variety. It can be done through student activism at both in and extracurricular programs [12]. Student activity is an essential element of this approach because it is the core of the school process through which knowledge, skills, and values are acquired. Therefore, schools have a role in maintaining multicultural student relationships [24]. The school also encourages harmony between people from various cultural and religious backgrounds [25-27], that's why culture can be a very effective tool in the learning process and transfer of multicultural Islamic values to students [38]. at the same time reinforced by the results of Geng's research (2020) which states that the more students learn cultural and national values, the easier it will be for students to contribute to society in the future [39].

Schools have a role in shaping the character of the nation, which has the task of preparing the potential of all school members, in this case, students, to appear and get used to good behavior. Based on research findings through interviews, multicultural Islamic education teaches and instills the importance of respecting cultural differences, customs, languages, and so on, respecting human rights as citizens based on Islam. In every subject, it is necessary to have multicultural values. Besides that, there is a need for extracurricular performances/events that show differences but unite.

Character formation that starts from multicultural values is very important to be applied in elementary schools, this is because theoretically, it will have implications for optimizing the absorption of values in students. This is because these times are very potential 
times for students to absorb all information on diversity and multicultural values that function in character building in the future. Theoretically, this phenomenon can be explained through Piaget's theory of development related to the concrete operational stage, which at this stage, between the ages of 7-11 years, students have begun to be able to develop thinking in an organized and rational manner. This high curiosity in the context of rationality can be used by educators as momentum to instill values contextually so that they are easily accepted and internalized in the character of students.

\subsection{Development of Multicultural Islamic Education}

Based on the search results at the two research locations, both at SD YPPSB 3 and SDN 002 Sangatta (both are state elementary school), it was found that two models were used according to the researcher's observations. The two models are the administrative model and the grass-root model. The curriculum development can be done through two approaches: (1) the top-down approach to the administrative model and (2) the grass-root model [40]. The top-down approach is used as a form of school acknowledgment of the central policy, the Ministry of Education and Culture, in establishing curriculum 13 as the national curriculum. In contrast, schools use the grass-root model approach to form flexibility for schools and teachers in developing the curriculum.

The top-down model is the classic curriculum development model and the most widely used. The idea of curriculum development with this model starts with education providers (policymakers) who use administrative procedures as policy directions. Curriculum development comes from high-ranking officials (Ministry of Education and Culture), then structurally carried out at lower levels. In this model, education officials form a steering committee consisting of education supervisors, principals, and core teachers. This steering committee is tasked with formulating general plans, principles, philosophical foundations, and general educational goals [41, p. 219]. While the grassroots model It is understood that curriculum development starts from an initiative by an individual teacher or a group of teachers or all teachers in a school who intends to solve the curriculum problems, they face in their schools by improving or developing them. This curriculum development can be related to one curriculum component, several fields of study, or all curriculum components [41].

Based on the search results of research at SD YPPSB 3 and SDN 002, Sangatta grouping curriculum components based on; 1. Core competencies, (2) essential competencies, (3) learning content, (4) subjects, and (5) teaching load. The research findings found that the multicultural Islamic learning process is based on unique, essential points in the multicultural Islamic education learning process at SD YPPSB 3 Sangatta: 1) Learning materials use the 2013 curriculum. This material contributes to the hidden curriculum in the form of multiculturalism, which goes on from generation to generation. 2) Religious teachers are teachers of Islam and teachers of Christianity, Catholicism, and Hinduism. The relationship between religious teachers has been running in harmony, mutual respect, and mutual support. It is essential in the learning process because the teacher's role is very strategic and determines the optimization of the learning process, especially for elementary school students. 3) Students also use multiple religions. They are taught religious subjects according to their respective religions. 4) The purpose of multicultural Islamic education is to foster faith, create religious people. 5) Learning materials include faith, worship, morals, tolerance, and developing religious culture. 6) Learning media are Al Quran, Teacher, Video, Image, Map, and PHBI. 7) Learning methods include lectures, questions and answers, assignments, memorization, practice, portfolios, personal approaches, and developing respectful communication. 8) Learning evaluation is carried out through daily tests, UTS, UAS, LKS, memorizing short letters,

While the research findings at SDN 002 Sangatta are as follows: 1) The learning materials uses the 2013 curriculum. This material contributes to the hidden curriculum (environmental customs) in the form of a fertile multiculturalism tradition passed down from generation to generation. 2) Multicultural Islamic education aims to develop faith, create religiously obedient people, have a noble character, and carry out religious teachings. 3) Learning materials include faith, worship, morals, tolerance, and developing religious culture. 4) Learning media are the Qur'an, teachers (people), pictures, and maps. 5) Learning methods include lectures, questions and answers, assignments, memorization, practice, portfolios, personal approaches, and developing respectful and togetherness communication.

The core competencies of Islamic education subjects that apply the 2013 curriculum are appropriate learning practices containing multicultural Islamic values. For this reason, after the learning process, students are expected to understand diversity in the environment. They can apply the importance of multicultural Islamic education in their daily activities. Multicultural Islamic religious education subjects do not stand alone as subjects in the two research locations, but multicultural Islamic values are integrated with several learning themes. Learning is carried out according to the learning theme.

Textbooks used in learning are in the form of student books and teacher books that have been determined by the government, in this case, the District Education Office. It is in line with learning media such as textbooks 
which also play a role in building multiculturalism $[29,30]$. The development of multicultural values in texts using analysis of four perspectives, namely by using argumentative analysis, content analysis, image analysis, and gender analysis, shows that the textbook's author primarily determines the content of a book. Riadi confirms the results of his research on a large elementary school class that the differences between the three texts are: The BSE he studied was influenced by the presence of different authors [42].

Muslich explained that a textbook is said to have feasibility if it contains four main elements: feasibility of presentation, content, language, and graphics. Based on the textbook assessment instrument developed by the National Education Standards Agency (BSNP), which includes: (1) Content feasibility includes: a) conformity of the material description with standard competency (SK) and basic competency (KD), b) accuracy of the material and c) material that supports learning. (2) Feasibility of presentation, including a) presentation techniques in the form of systematic presentation, coherence of presentation, and balance between chapters. b) Presentation of learning, which includes studentcentered, developing process skills, paying attention to work safety aspects, and c) completeness of presentation, including the introduction, content, and closing. (3) Assessment of language eligibility, including suitability with the level of student development, communicative language, coherence, and integration of the flow of thought. And (4) Graphical feasibility assessment, including book size with ISO standards, book cover design, and book content design [43, pp. 291-292].

Based on the document analysis of the material's content in Islamic religious education subjects, students must achieve the competencies that students must achieve from grade one to grade six. Thus, students can understand that interacting with other people of different ethnicities, races, and religions is not disturbing. Therefore, respect for every nationality, race, culture, and religion arises by applying multicultural learning in their lives through learning assignments. The process is carried out by organizing material resources without changing the concept, structure, objectives, and characteristics of core competencies. Both schools have made full efforts to learn following the curriculum provisions that the government has planned.

\subsection{Implementation of Multicultural Islamic Education Values}

Based on the search results at the two research loci, both at SD YPPSB 3 and SDN 002 Sangatta, it was found that the strategy for implementing multicultural Islamic education at the school level was carried out through four things as; (1) integration of multicultural Islamic values through each subject, (2) integration of multicultural Islamic values through extracurricular activities, (3) habituation of daily life in the school environment, and (4) habituation of daily life at home. The following image is presented.

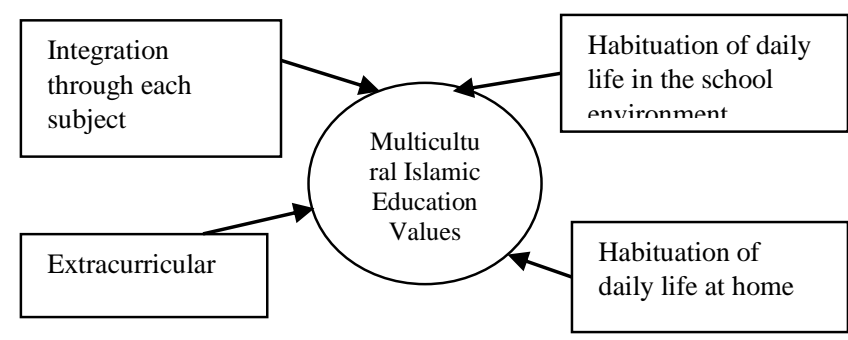

Figure 2 Implementation of multicultural Islamic education values.

The implementation of multicultural Islamic values integrated into KBM activities in each subject is a shared responsibility between school principals, teachers, students, and stakeholders. The development and inculcation of this value can be done by direct integration through the subjects in the classroom. Multicultural Islamic values and positive norms in each subject can be developed and internalized by students in teaching and learning activities. The cultivation and development of these values rely on the cognitive domain, but the teacher should develop how to teach multicultural Islamic values in students' real lives. It is in line with encouraging harmony among people from various cultural and religious backgrounds[25-27].

Integration of multicultural Islamic values through extracurricular activities can be done in practice. The school holds an extracurricular program outside of learning hours with the characteristics of the community environment where the school is located. Several extracurricular activities at the research location include pencak silat, language development, choir, drawing, etc. Extracurricular activities are followed by students with interests and interests there, consisting of different religious, ethnic, and cultural backgrounds. These interactions occur, which will indirectly foster a moderate attitude and multicultural behavior.

In teaching multicultural Islamic values, the school is not enough to teach materially, habituating daily life in the school environment. Still, it is necessary to integrate multicultural Islamic values into the school's daily activities. For example, (1) students are taught to greet the teacher when passing by, or shake hands with the teacher when returning from school (ethical teachings and building intimacy and bonds between teachers and students), (2) praying before studying according to religious teachings, (3) using the Indonesian language in all school activities so that students have an attachment to the Indonesian homeland, (3) share breakfast with friends during breaks to teach them to have a social spirit, and (4) cooperate cleaning classrooms and school grounds as teaching of cooperation and responsibility. By familiarizing students with values through multicultural 
school daily activities, students are expected to have moderate attitudes and behavior. It is in line with the findings of Raihani's research that through student activities, both in and extracurricular programs, students can gain knowledge, skills, and multicultural values [12]. Civic and multicultural education has a very important role in the world of education in producing young people who are sensitive to social issues and willing to take action on the needs of others [44].

Learning multicultural Islamic values will be perfect if parents and the community are also taught in the home environment, habituating daily life at home. The community's social, artistic, and cultural backgrounds are still explored and introduced to children from an early age through activities in the community. The values of mutual help, community service, cooperation in the surrounding environment will foster students to be environmentally friendly and moderate. The multicultural Islamic value is also in line with the character of the Indonesian nation, which is based on Pancasila, and the noble values of the Indonesian government, namely the spirit of patriotism and nationality. Such things are introduced and instilled from an early age using creative play, traditional games, traditional and modern songs, and jointly protecting the surrounding environment.

\section{CONCLUSION}

Multicultural Islamic education values formulated through a school leadership, while curriculum development is through a top-down approach with an administrative and grassroots model.

In its implementation in developing a multicultural Islamic education curriculum: a) learning materials use the 2013 curriculum. b) religious teachers are teachers of Islam and teachers of Christianity, Catholicism, and Hinduism. c) students learn based on their respective religions. 4) the purpose of multicultural Islamic education is to foster faith. 5) learning materials include faith, worship, morals, tolerance, and developing religious culture. 6) learning media are the Koran, teachers, videos, pictures, maps, and PHBI. 7) learning methods include lectures, questions and answers, assignments, memorization, practice, and portfolios. 8) learning evaluation is carried out through daily tests, midterm, final-term, and student worksheet, memorizing short letters, and worship practices.

The strategy for implementing the values of multicultural Islamic education is carried out in four ways; (1) integration of multicultural Islamic values through each subject, (2) integration of multiculturalbased character values through extracurricular activities, (3) habituation of daily life in the school environment, and (4) habituation of daily life day at home.

\section{AUTHORS' CONTRIBUTIONS}

All authors have different roles in the accomplishment of the study. For this manuscript, they contributed equally to the process of drafting, revision, and approval of the final revision.

\section{REFERENCES}

[1] Chairy, J. Syahrivar, Bika Ambon of Indonesia: History, culture, and its contribution to tourism sector, Journal of Ethnic Foods 6(2) (2019) 2-7. DOI: https://doi.org/10.1186/s42779-019-0006-6

[2] Raihani, A model of Islamic teacher education for social justice in Indonesia a critical pedagogy perspective, Journal of Indonesian Islam 14(1) (2020) 163-186. DOI: https://doi.org/10.15642/JIIS.2020.14.1.163-186

[3] Sismanto, Riswadi, Forms of Cooperation Between Religions; A Tafsir Perspektif, Syamil Journal of Islamic Education 9(1) (2021) 21-38. DOI: https://doi.org/10.21093/sy.v9i1.3201

[4] H. A. R. Tilaar, Multikulturalisme, Bahasa Indonesia, dan Nasionalisme dalam Sistem Pendidikan Nasional, Jurnal Dialektika 1(2) (2014).

[5] N. Sulistyobudi, B. Suta, Salamun, Implementasi Pendidikan Multikultural di SMA Daerah Istimewa Yogyakarta, Yogyakarta: Balai Pelestarian Nilai Budaya (BPNB) Yogyakarta, 2014.

[6] L. Parker, Religious education for peaceful coexistence in Indonesia?, South East Asia Research 22(4) (2014) 487-504. DOI: https://doi.org/10.5367/sear.2014.0231

[7] T. K. Christiani, The future of religiosity education in catholic schools in Yogyakarta, Indonesia, South East Asia Research 22(4) (2014) 525-540. DOI: https://doi.org/10.5367/sear.2014.0233

[8] M. Muhlisin, M. Syaifuddin, The Implementation of Integrated Islamic Education Model at MAN Insan Cendekia Pekalongan, Edukasia Islamika 5(1) (2020) 68.6 DOI: https://doi.org/10.28918/jei.v5i1.255

[9] Z. Baidhawy, Building harmony and peace through multiculturalist theology-based religious education: An alternative for contemporary Indonesia, British Journal of Religious Education 29(1) (2007) 15-30. DOI: https://doi.org/10.1080/01416200601037478

[10] T. Arphattananon, Multicultural education in Thailand, Intercultural Education 29(2) (2018) 149162.

DOI: https://doi.org/10.1080/14675986.2018.1430020 
[11] Nurwanto, C. M. Cusack, Correction to: Addressing multicultural societies: lessons from religious education curriculum policy in Indonesia and England, Journal of Religious Education 65(1-3) (2017) 95-95. DOI: https://doi.org/10.1007/s40839017-0045-5

[12] Raihani, Education for multicultural citizens in Indonesia: policies and practices, Compare: A Journal of Comparative and International Education 48(6) (2018) 992-1009. DOI: https://doi.org/10.1080/03057925.2017.1399250

[13] J. A. Banks, C. A. M. Banks, Multicultural Education; Issues and Perspectives, 8th ed, John Wiley \& Sons, 2013.

[14] R. Jeffcoate, Why multicultural education?, Educ. 3-13 Int. J. Primary, Elementary Early Years Education 9(1) (1970) 4-7. DOI: https://doi.org/10.1080/03004278185200021

[15] C. E. Sleeter, C. A. Grant, An analysis of multicultural education in the United States, in: Multiculturalism in Education and Teaching The selected works of Carl A. Grant, 4 (2014) 57-82. DOI: https://doi.org/10.4324/9781315857145

[16] W. E. Piland, B. Barnard, Multicultural Education in the Classroom, Community College Journal of Research and Practice 20(1) (1996) 49-63. DOI: https://doi.org/10.1080/1066892960200106

[17] C. I. Bennett, Genres of research in multicultural education, Review of Educational Research 71(2) (2001) 171-217. DOI: https://doi.org/10.3102/00346543071002171

[18] Z. Arsal, Critical multicultural education and preservice teachers' multicultural attitudes, Journal of Multicultural Education13(1) (2019) 106-118. DOI: https://doi.org/10.1108/JME-10-2017-0059

[19] T. A. Wasonga, Multicultural education knowledgebase, attitudes and preparedness for diversity, International Journal of Education Management 19(1) (2005) 67-74. DOI: https://doi.org/10.1108/09513540510574966

[20] Y. Xu, C. Hao, M. E. Huennekens, Effects of a multicultural perspectives course on teacher candidates' intercultural competence, Journal of Multicultural Education 10(1) (2016) 72-86. DOI: https://doi.org/10.1108/JME-07-2015-0025

[21] J. M. Magogwe, L. E. Ketsitlile, Pre-service teachers' preparedness for teaching multicultural students, Journal of Multicultural Education 9(4) (2015) 276-288. DOI: https://doi.org/10.1108/JME$11-2014-0040$
[22] E. Oikonomidoy, Conceptual collective online reflection in multicultural education classes, Multicultural Education \& Technology Journal 3(2) (2009) 130-143. DOI: https://doi.org/10.1108/17504970910967564

[23] Z. Arsal, The examination of courses in the teacher education programs in terms of multicultural education, Journal of Multicultural Education 9(4) (2015) 263-275. DOI: https://doi.org/10.1108/JME11-2014-0035

[24] T. Y. Harjatanaya, C. Y. Hoon, Politics of multicultural education in post-Suharto Indonesia: a study of the Chinese minority, Compare 50(1) (2020) 18-35. DOI: https://doi.org/10.1080/03057925.2018.1493573

[25] T. Budirahayu, M. Saud, Proposing an Integrated Multiculturalism Learning System: A Study from Indonesian Schools, Asia-Pacific Educational Research 30(2) (2021) 141-152. DOI: https://doi.org/10.1007/s40299-020-00521-1

[26] A. Masry-Herzallah, M. Amzalag, From theory to practice: Jewish and Arabs students in academia practice multicultural education, International Journal of Comparative Education and Development (2021). DOI: https://doi.org/10.1108/ijced-06-2020-0031

[27] A. Halai, R. Barwell, Intellectual and attitudinal challenges, in: The Proceedings of the 12th International Congress on Mathematical Education, P (2015) 539-544. DOI: https://doi.org/10.1007/978-3-319-12688-3

[28] Raihani, Report on multicultural education in pesantren, Compare, 42(4) (2012) 585-605. DOI: https://doi.org/10.1080/03057925.2012.672255

[29] B. Setyono, H. P. Widodo, The representation of multicultural values in the Indonesian Ministry of Education and Culture-Endorsed EFL textbook: a critical discourse analysis, Intercultural Education 30(4) (2019) 383-397. DOI: https://doi.org/10.1080/14675986.2019.1548102

[30] M. A. Nugroho, Embedding Multicultural Values in Islamic Education: A Portrayal of Contemporary Indonesian Textbooks, Edukasia Islam 4(2) (2019) 226. DOI: https://doi.org/10.28918/jei.v4i2.2298

[31] A. B. P. Hasan, E. Suwarni, Policies and Practices for Promoting Multicultural Awareness of Indigenous Early Childhood Education in Indonesia, International Journal of Child Care and Education Policy 6(1) (2012) 63-94. DOI: https://doi.org/10.1007/2288-6729-6-1-63 
[32] N. S. B. S. Salamun, Implementasi Pendidikan Multikultural di Sekolah Inklusi SMP Tumbuh Yogyakarta, 2014

[33] A. F. Noor, Sugito, Multicultural Education Based in the Local Wisdom of Indonesia for Elementary Schools in the 21st Century, Journal of International Social Studies 9(2) (2019) 94-106.

[34] M. Muslih, Construction of the Qur'anic Values as the Basis for Islamic Education Development: A Study of Abdullah Saeed's Thought, Edukasia Islam 5(2) (2020) 139-157. DOI: https://doi.org/10.28918/jei.v5i2.2534

[35] R. C. Bogdan, S. K. Biklen, Qualitative Research for Education: An introduction to theory and methods, Boston: Allyn and Bacon, 1982.

[36] Sismanto, The Effectiveness of Multiple Inteligence Based Class Grouping Learning Method in Teaching Science at Grade VII SMP YPPSB PT. Kaltim Prima Coal," in: Prosiding Seminar Nasional Pendidikan Biologi 2016, yang diselenggarakan oleh Prodi Pendidikan Biologi FKIP Universitas Muhammadiyah Malang, 2016, pp. 168-174.

[37] Sismanto, Policy Analysis of Teacher Professional Improvement in YPPSB Elementary School, International Journal of Asian Education 2(1) (2021) 79-87. DOI: https://doi.org/10.46966/ijae.v2i1.92

[38] A. Maimun, A. Indiyanto, M. Mujab, Educating islamic values through wiwitan tradition, Journal of Indonesian Islam 14(2) (2020). DOI: https://doi.org/10.15642/JIIS.2020.14.2.359-386

[39] L. Geng, Q. Zheng, X. Zhong, L. Li, Longitudinal Relations Between Students' Engagement and Their Perceived Relationships with Teachers and Peers in a Chinese Secondary School, Asia-Pacific Eduaction Research 29(2) (2020). DOI: https://doi.org/10.1007/s40299-019-00463-3

[40] M. T. Nugraha, Pengembangan Model Kurikulum Pendidikan Agama Islam (PAI) Menuju Masyarakat Ekonomi Asean (MEA), Jurnal At-Turats 10(1) (2016) 13-21.

[41] S. Sabda, Pengembangan Kurikulum (Tinjauan Teoritis), 2016.

[42] Riadi, Analisis Buku Ajar (BSE) PAI SD Kelas Tinggi (Studi Analisis di SD I Lembah Sari Kecamatan Batu Layar, Ibtida'ia Jurnal PGMI F 3(1) (2018) 110-136.

[43] M. Muslich, Text Book Writing, Yogyakarta: ArRuzz Media, 2010.
[44] K. C. Barton, L. C. Ho, Cultivating sprouts of benevolence: a foundational principle for curriculum in civic and multicultural education, Multicultural Education Revew 12(3) (2020). DOI: https://doi.org/10.1080/2005615X.2020.1808928 